\title{
Peningkatan Kemampuan Kerjasama dalam Tim Melalui Pembelajaran Berbasis Lesson Study
}

\author{
Bekti Wulandari ${ }^{1}$, Fatchul Arifin ${ }^{2}$, Dessy Irmawati ${ }^{3}$ \\ 1) 2) ${ }^{3)}$ Pendidikan Teknik Elektronika, Fakultas Teknik Universitas Negeri Yogyakarta, \\ E-mail : bektiwulandari@uny.ac.id
}

\begin{abstract}
ABSTRAK
Penelitian ini bertujuan untuk meningkatkan kualitas pembelajaran pada mata kuliah Praktik Pengolahan Sinyal Digital dan menumbuhkan aspek kerjasama yang baik dalam satu tim pada mata kuliah Praktik Pengolahan Sinyal Digital. Peningkatan kualitas pembelajaran ini menerapkan metode pembelajaran problem based learning. Dalam penelitian ini menerapkan metod lesson study model Lewis (2002) dan pelaksanaanya dilakukan dalam 3 kegiatan, yaitu: 1) Perencanaan (plan); 2) Pelaksanaan dan Observasi (do); 3) Refleksi (see). Subjek penelitian adalah mahasiswa S1 Prodi Pendidikan Teknik Elektronika dan data diperoleh dengan cara observasi dan perekaman. Hasil penelitian menunjukkan bahwa terjadi peningkatan kualitas proses pembelajaran. Dilihat dari jumlah mahasiswa yang aktif semakin banyak, perkuliahan tidak membosankan karena sebagian besar mahasiswa kelihatan antusias dalam belajar. Bagi dosen juga ada keuntungannya yaitu dapat melakukan kolaborasi dengan teman sejawat dalam upaya untuk memperbaiki pembelajaran. Melalui pembelajaran lesson study ini selain dapat meningkatkan kualitas pembelajaran sekaligus juga dapat menumbuhkan aspek kerjasama yang baik dalam satu tim pada mata kuliah Praktik Pengolahan Sinyal Digital. Hal ini terlihat dari tanggung jawab dalam pengambilan keputusan, tidak memisahkan diri dari orang lain, interaksi terhadap sumber belajar, interaksi antar mahasiswa, aktifitas menyelesaikan masalah dan mahasiswa tidak pasif.
\end{abstract}

Kata kunci: Lesson study, kerjasama, problem based learning

\section{PENDAHULUAN}

Mata kuliah Praktik Pengolahan Sinyal Digital di Prodi Pendidikan Teknik Elektronika Jurusan Pendidikan Teknik Elektronika FT UNY merupakan mata kuliah yang berorientasi pada pemahaman dan ketrampilan peserta didik dalam mengolah sinyal analog menjadi sinyal digital dan sebaliknya. Selain itu juga mencakup sinyal dan sistem waktu diskrit, DTFT (Discrete Time Fourier Transform), Fast Fourier Transform dan aplikasinya pada analisis spektrum sinyal, Transformasi $\mathrm{Z}$ dan inversnya, perancangan filter digital IIR dan FIR. Pembelajaran praktik pada mata kuliah ini memberikan tantangan sendiri bagi pengajar untuk dapat mensimulasikan pengolahan sinyal menggunakan Matlab 7. Praktik Pengolahan Sinyal Digital menggunakan simulasi matlab karena tersedianya toolbox pada software tersebut dan mendukung dalam pembuatan grafik. Banyak mahasiswa yang belum mempunyai logika pemrograman yang baik dan lemah dalam mengerjakan bahan diskusi.
Hal ini disebabkan karena mahasiswa pasif dalam praktik yang sekedar mengikuti script yang ada di jobsheet. Ditambah lagi selama ini proses pembelajaran yang diterapkan dalam perkuliahan praktik pengolahan sinyal digital masih menggunakan metode teacher centered learning dimana peran dosen masih sangat dominan sehingga berdampak pada kurang mandirinya mahasiswa.

FT UNY sebagai salah satu lembaga yang menghasilkan calon guru dan dimungkinkan juga sebagai tenaga kerja di industri sehingga diharapkan mampu mengikuti tuntutan dalam dunia kerja. Lingkungan kerja selain ketrampilan dan pengetahuan juga dibutuhkan kerjasama (teamwork) untuk menyelesaikan suatu permasalahan. Menurut Slamet PH (2011), karakter kerja yang dibutuhkan dunia kerja meliputi: etika kerja, rasa keingintahuan, sifat dapat dipercaya, disiplin diri, kejujuran, komitmen, tanggung jawab, respek terhadap diri sendiri dan orang lain, toleransi, kerja keras, hubungan kerja yang baik, integritas, perilaku yang baik, 
komunikasi kegigihan, motivasi kerja tinggi, kerjasama yang baik, inisiatif, keberanian moral, kerajinan, daya adaptasi, pengendalian diri, pembelajar yang cepat, keinginan untuk belajar hal-hal yang baru, kemampuan cara belajar, keluwesan dan kewirausahaan.

Sesuai dengan pendapat Bloom (dalam Winkel: 1999) membagi prestasi belajar ke dalam tiga aspek kognitif, afektif, dan psikomotorik, seperti yang terdapat pada kompetensi yang diharapkan dalam Mata kuliah Praktik Pengolahan Sinyal Digital meliputi kompetensi kognitif, afektif dan psikomotorik. Kompetensi kognitif dan psikomotorik bersinggungan dengan peningkatan pengetahuan dan ketrampilan mahasiswa dalam mengolah sinyal digital, sedangkan kompetensi afektif mengarah pada kerjasama dalam menyelesaikan suatu masalah. Selama ini pelaksanaan pembelajaran praktik Pengolahan Sinyal Digital berlangsung secara individu, sehingga kemampuan kerjasama sama sekali tidak terbentuk.

Permasalahan yang dihadapi pada pelaksanaan mata kuliah praktik Pengolahan Sinyal Digital seperti tersebut diatas perlu diatasi. Apabila tidak segera diatasi maka mahasiswa di samping akan mengalami kesulitan dalam menempuh mata kuliah juga menghambat tumbuhnya sikap kerjasama yang dituntut oleh dunia kerja. Berdasarkan permasalahan diatas, untuk meningkatkan kemandirian mahasiswa dan menumbuhkan sikap kerja sesuai dengan tuntutan dunia kerja maka diperlukan perubahan budaya dalam perkuliahan dari teacher centered learning ke student centered learning. Oleh karena itu perlu dikembangkan model pembelajaran yang mampu mengakomodasi permasalahan di atas. Strategi pembelajaran yang dipilih adalah pembelajaran berbasis Lesson Study dengan mengembangkan dan menerapkan metode Problem Based Learning.

\section{Pembelajaran Lesson Study}

Lesson Study merupakan bentuk suatu kolaboratif, dasar pengembangan profesional sekolah untuk memperoleh peningkatan dalam pembelajaran dan pengajaran melalui metode professional sharing (David Burghes, 2009). Lebih lanjut Wang Iverson dan Yoshida (2005) mengemukakan beberapa definisi yang berkaitan dengan lesson study antara lain:

1. Lesson study (jugyokenkyu) merupakan bentuk pengembangan keprofesionalan dosen dalam pembelajaran, yang dikembangkan di Jepang, di dalamnya dosen secara sistematis dan kolaboratif melaksanakan penelitian pada proses belajar mengajar di dalam kelas untuk pengembangan dan pengalaman pembelajaran yang diampu dosen.

2. Lesson study menjadikan dosen belajar tentang pengembangan dan peningkatan kualitas pembelajaran yang diampu.

3. Lesson study merupakan pendekatan komprehensif untuk pembelajaran yang profesional dilaksanakan secara tim melalui tahapan-tahapan perencanaan, implementasi pembelajaran di dalam kelas dan observasi, refleksi, dan diskusi data hasil observasi serta pengembangan pembelajaran lebih lanjut.

Menurut Lewis (2002) pembelajaran yang berbasis pada lesson study perlu dilakukan karena beberapa alasan antara lain lesson study merupakan suatu cara efektif yang dapat meningkatkan kualitas pembelajaran yang dilakukan dosen dan aktivitas belajar mahasiswa.

Lesson study memberikan banyak kesempatan bagi dosen untuk berkolaborasi dengan sesama sejawat bidang ilmu, sehingga kreatifitas dalam proses pembelajaran dapat merubah prespektif dosen tentang pembelajaran serta untuk belajar melihat proses mengajar yang dilakukan dosen dari prespektif mahasiswa. Lesson Study dilaksanakan melalui tiga tahapan, yaitu Plan (Perencanaan), Do (Pelaksanaan), dan See (Refleksi) (Lewis (2002); Slamet mulyono (2007); Kadarisman (2009)). Tiga tahapan ini merupakan satu siklus pembelajaran. Tahapan Plan merupakan perancangan pembelajaran agar mahasiswa 
dapat belajar dari materi pembelajaran secara aktif. Tahap Do merupakan pelaksanaan pembelajaran yang telah dirancang dalam tahap Plan. Setelah pembelajaran selesai langsung diadakan pertemuan antara dosen model dan observer dalam tahap refleksi. Semua orang yang terlibat dalam Lesson Study dapat belajar dari pembelajaran karena pembelajaran tersebut adalah pembelajaran kita. Lesson Study dimaksudkan agar: (a) semua mahasiswa dapat berpartisipasi dalam pembelajaran tanpa kecuali dan (b) dosen menerapkan hasil yang diperoleh dari refleksi pembelajaran.

Sedangkan Bill Cerbin dan Bryan Kopp dari University of Wisconsin mengetengahkan enam tahapan dalam Lesson Study, berikut ini:

a. Form a Team: membentuk tim sebanyak 3-6 orang yang terdiri guru yang bersangkutan dan pihak-pihak lain yang kompeten serta memilki kepentingan dengan Lesson Study.

b. Develop Student Learning Goals: anggota tim memdiskusikan apa yang akan dibelajarkan kepada peserta didik sebagai hasil dari Lesson Study.

c. Plan the Research Lesson: guru-guru mendesain pembelajaran guna mencapai tujuan belajar dan mengantisipasi bagaimana para peserta didik akan merespons.

d. Gather Evidence of Student Learning: salah seorang guru tim melaksanakan pembelajaran, sementara yang lainnya melakukan pengamatan, mengumpulkan bukti-bukti dari pembelajaran peserta didik.

e. Analyze Evidence of Learning: tim mendiskusikan hasil dan menilai kemajuan dalam pencapaian tujuan belajar peserta didik

f. Repeat the Process: kelompok merevisi pembelajaran, mengulang tahapan-tahapan mulai dari tahapan ke-2 sampai dengan tahapan ke-5 sebagaimana dikemukakan di atas, dan tim melakukan sharing atas temuan-temuan yang ada.
Problem Based Learning

Menurut Maggi Savin dan Claire Howell (2004:8) Problem-based learning (PBL) dipopulerkan oleh Barrow and Tamblyn pada tahun 1980 di Kanada. Metode $P B L$ merupakan metode pembelajaran dengan menghadapkan siswa pada permasalahan-permasalahan dunia nyata (Maggi Savin dan Claire Howell (2004:8); Barbara (2001:1); Linda Torp dan Sara Sage (2002:15); Tan (2003:7); Glazer (2001)). PBL merupakan pembelajaran aktif progresif dan pendekatan pembelajaran berpusat pada masalah yang tidak terstruktur yang digunakan sebagai titik awal dalam proses pembelajaran. PBL menggunakan berbagai macam kecerdasan yang diperlukan untuk melakukan konfrontasi terhadap tantangan dunia nyata, kemampuan untuk menghadapi segala sesuatu yang baru dan masalah-masalah yang dimunculkan. $P B L$ sering dilakukan dengan pendekatan tim melalui penekanan pada pembangunan keterampilan yang berkaitan dengan pengambilan keputusan, diskusi, pemeliharaan tim, manajemen konflik, dan kepemimpinan tim.

Karakteristik metode $P B L$ adalah: (1) pembelajaran dimulai dengan pemberian masalah yang mengambang yang berhubungan dengan kehidupan nyata; (2) masalah dipilih sesuai dengan tujuan pembelajaran; (3) siswa menyelesaikan masalah dengan penyelidikan auntetik; (4) secara bersama-sama dalam kelompok kecil, siswa mencari solusi untuk memecahkan masalah yang diberikan; (5) guru bertindak sebagai tutor dan fasilitator; (6) siswa bertanggung jawab dalam memperoleh pengetahuan dan informasi yang bervariasi, tidak dari satu sumber saja; (7) siswa mempresentasikan hasil penyelesaian masalah dalam bentuk produk tertentu. Produk dalam hal ini adalah berupa suatu pemrograman (Tan (2004:8); Hallinger dan Edwin (2007:89); Maggi Salvin dan Claire Howell (2004:4); Ibrahim et. al. (2009:155); Arends (2008:42)).

Menurut Pierce dan Jones (Rusman 2012:242) kejadian yang harus muncul dalam implementasi $P B L$ adalah: (1) keterlibatan 
yaitu mempersiapkan siswa untuk berperan sebagai pemecah masalah dengan bekerjasama, (2) inquiry dan investigasi yaitu mengeksplorasi dan mendistribusikan informasi, (3) performansi yaitu menyajikan temuan, (4) tanya jawab tujuannya untuk menguji keakuratan dari solusi, (5) refleksi terhadap pemecahan masalah.

Langkah-langkah metode problem based learning yang dilakukan dalam penelitian lesson study ini adalah :

1. memberikan permasalahan kepada peserta didik dimana permasalahan tersebut berhubungan dengan kehidupan seharihari

2. guru mengorganisasikan peserta didik dalam beberapa kelompok

3. guru membantu peserta didik mengorganisasikan tugas belajar sesuai dengan masalah

4. peserta didik mengumpulkan pengetahuan dan melakukan percobaan sesuai dengan pemecahan masalah yang diberikan

5. peserta didik mengembangkan dan menyajikan hasil karya yang berupa suatu program.

(Arends (2008:57); Amir (2009:24); Fogarty dalam Rusman(2012:243))

\section{Kerjasama}

Kerjasama merupakan sifat sosial, bagian dari kehidupan masyarakat yang tidak dapat dielakkan oleh manusia dalam kehidupan sehari-hari. Dalam bidang pendidikan muncul berbagai metode pembelajaran yang lebih menitikberatkan pada kerjasama, antara lain seperti diungkapkan oleh Johnson \& Johnson (1991), Hill \& Hill (1993) serta Slavin (1995), pada umumnya memberikan batasan tentang pengertian kerjasama mirip satu sama lain. Kerjasama adalah bekerja bersama untuk mencapai tujuan yang diinginkan bersama (Johnson \& Johnson,1991).

Menurut Johnson dan Johnson (1991), karakteristik suatu kelompok kerjasama terlihat dari adanya lima komponen yang melekat pada program kerjasama tersebut, yakni:

1. adanya saling ketergantungan yang positif diantara individu-individu dalamkelompok tersebut untuk mencapai tujuan

2. adanya interaksi tatap muka yang dapat meningkatkan sukses satu sama lain diantara anggota kelompok

3. adanya akuntabilitas dan tanggungjawab personal individu

4. adanya keterampilan komunikasi interpersonal dan kelompok kecil

5. adanya keterampilan bekerja dalam kelompok.

Menurut Michaelis (1986) keterampilan kerjasama merupakan hal penting yangpaling diunggulkan dalam kehidupan masyarakat utamanya budaya demokratis, dan merupakan salah satu indikator dari lima indikator perilaku sosial, yakni tanggungjawab, peduli pada oranglain, bersikap terbuka, dan kreativitas.

\section{METODE}

Penelitian dilaksanakan di Program Studi Pendidikan Teknik Elektronika Jurusan Pendidikan Teknik Elektronika FT-UNY. Waktu pelaksanaan penelitian pada perkuliahan semester gasal tahun akademik 2014/2015.

Metode yang diterapkan adalah lesson study model Lewis (2002). Pelaksanaanya dilakukan dalam 3 kegiatan, yaitu: 1) Perencanaan (plan); 2) Pelaksanaan dan Observasi (do); 3) Refleksi (see). Sebelum dilakukan penelitian, diperlukan 2 tahapan persiapan yaitu membentuk kelompok lesson study dan memfokuskan lesson study. Dalam tahap membentuk kelompok ini ditentukan anggota kelompok sebagai tim pengajar sekaligus menentukan seorang dosen dari anggota kelompok sebagai dosen pelaksana pembelajaran (dosen model). Kegiatan dalam tahap kedua memfokuskan lesson study yaitu: menyepakati tentang tema 
permasalahan, focus permasalahan dan tujuan utama pemecahan masalah, termasuk identifikasi kualitas mahasiswa, kualitas ideal dan kesenjangan yang terjadi; menentukan topik-topiknya.

Pada tahap perencanaan, anggota kelompok menyusun Rencana Pembelajaran (RPP), petunjuk pelaksanaan pembelajaran, serta lembar observasi pembelajaran. Selanjutnya tahap pelaksanaan dan observasi (do). Rencana pembelajaran yang telah disusun bersama diimplementasikan di kelas oleh dosen pelaksana pembelajaran. Anggota kelompok yang lain sebagai observer. Selanjutnya pada tahap terakhir yaitu see, yang digunakan sebagai masukan untuk perbaikan atau revisi rencana pembelajaran berikutnya.

Subjek penelitian ini adalah mahasiswa S1 kelas A Program Studi Pendidikan Teknik Elektronika yang mengambil mata kuliah Praktik Pengolahan Sinyal Digital pada semester gasal tahun akademik 2014/2015.

Pengumpulan data dilakukan dengan teknik observasi dan perekaman. Teknik observasi dan perekaman digunakan untuk merekam kualitas pembelajaran. Lembar observasi digunakan untuk mengetahui kualitas pembelajaran praktik teknik digital. Lembar observasi berisi tentang komponen kegiatan mahasiswa meliputi: tanggung jawab dalam pengambilan keputusan, tidak memisahkan diri dari orang lain, interaksi terhadap sumber belajar, interaksi antar mahasiswa, aktifitas menyelesaikan masalah dan mahasiswa tidak pasif.

Data hasil observasi dianalisis secara deskriptif untuk mengetahui kualitas pembelajaran praktik teknik digital dan tumbuhnya kerjasama dalam menyelesaikan masalah. Analisis data untuk karakter kerja dilakukan secara kualitatif dengan 4 kriteria yaitu :

BT : Belum Terlihat (apabila peserta didik belum memperlihatkan tanda- tanda awal perilaku yang dinyatakan dalam indikator),
MT : Mulai Terlihat (apabila peserta didik sudah mulai memperlihatkan adanya tanda-tanda awal perilaku yang dinyatakan dalam indikator tetapi belum konsisten),

MB : Mulai Berkembang (apabila peserta didik sudah memperlihatkan berbagai tanda perilaku yang dinyatakan dalam indikator dan mulai konsisten),

MM : Mulai Membudaya (apabila peserta didik terus menerus memperlihatkan perilaku yang dinyatakan dalam indikator secara konsisten).

\section{HASIL DAN PEMBAHASAN}

Pertama yang dilakukan dalam penelitian ini adalah observasi. Observasi dilakukan sebelum Lesson study dilaksanakan yang digunakan untuk mengetahui kondisi awal proses pembelajaran dan aktivitas mahasiswa sebelum diberikan perlakuan. Dalam observasi ini diperoleh hasil bahwa tanggungjawab mahasiswa dalam mengambil keputusan serta aktivitas dalam menyelesaikan permasalahan yang diberikan belum terlihat. Hal ini dapat dilihat dalam Tabel 1.

Tabel 1. Observasi Awal

\begin{tabular}{|l|l|c|}
\hline \multicolumn{1}{|c|}{ No } & \multicolumn{1}{|c|}{ Aspek pengamatan } & Hasil \\
\hline \multicolumn{2}{|l|}{ Kerjasama } & BT \\
\hline 1 & $\begin{array}{l}\text { Tanggungjawab dalam } \\
\text { pengambilan keputusan }\end{array}$ & MT \\
\hline 2 & $\begin{array}{l}\text { Tidak memisahkan diri dari } \\
\text { orang lain }\end{array}$ & MT \\
\hline 3 & $\begin{array}{l}\text { Interaksi terhadap sumber } \\
\text { belajar }\end{array}$ & $\begin{array}{l}\text { MT } \\
\text { (dalam satu kelompok) }\end{array}$ \\
\hline 5 & $\begin{array}{l}\text { Aktifitas menyelesaikan } \\
\text { masalah }\end{array}$ & BT \\
\hline 6 & Mahasiswa tidak Pasif & BT \\
\hline
\end{tabular}

Selanjutnya, tahapan lesson study dapat dijelaskan sebagai berikut:

1. Perencanaan 
Perencanaan (plan) dilakukan dengan cara diskusi sesama peneliti untuk membuat tata cara pelaksanaan, penetapan materi pembelajaran, dan waktu pelaksanaan. Diskusi menghasilkan kesepahaman mengenai rencana tindakan untuk meningkatkan kualitas dan membangun kerja sama mahasiswa melalui pembelajaran berbasis lesson study. Setelah terjadi kesepahaman dilanjutkan diskusi tentang pokok-pokok yang harus dilakukan dalam menyusun rancangan pembelajaran, kemudian menentukan jumlah kelompok dan masing-masing anggota kelompok harus bersifat heterogen dilihat dari segi kemampuan akademiknya. Tugas dosen model selama proses pembelajaran berlangsung adalah menyampaikan tujuan, materi pembelajaran, membagi tugas yang harus dikerjakan oleh mahasiswa dalam kelompok, menyampaikan tata cara mahasiswa bekerja dalam kelompok, mengobservasi mahasiswa dalam kelompok, mengevaluasi kerja mahasiswa, memberi penguatan,dan merangkum materi pembelajaran. Dalam proses pembelajaran akan dilakukan pengamatan kegiatan mahasiswa. Adapun komponen kegiatan mahasiswa yang diamati adalah tanggungjawab dalam pengambilan mahasiswa, tidak memisahkan diri dari orang lain, interaksi terhadap sumber belajar, interaksi antar mahasiswa, rasa keingintahuan, aktivitas menyelesaikan masalah, mahasiswa pasif (misalnya melamun, topang dagu, dsb).

Langkah selanjutnya adalah melakukan perencanaan pelaksanaan perkuliahan diantaranya dengan membagi mahasiswa menjadi 5 kelompok yang masing-masing kelompok terdiri dari 4 mahasiswa. Masingmasing kelompok diwajibkan menyelesaikan job praktikum dengan cara yang yang kemungkinan bisa berbeda. Selain perencanaan tersebut, tim peneliti membua trancangan pembelajaran dengan menekankan: (1) semua mahasiswa diwajibkan menyiapkan sumber belajar untuk praktikum,(2) diminta untuk berpakaian lebih rapi menggunakan baju praktikum, (3) menekankan kerjasama antaranggota kelompok dalam menyelesaikan masalah, (4) memberi kesempatan kepada mahasiswa untuk lebih berinovasi dan kreatif dalam melakukan praktikum.

\section{Pelaksanaan dan Observasi}

Kegiatan pembelajaran diorientasikan pada aktivitas mahasiswa dalam bekerjasama dalam kelompok. Dalam kegiatan pelaksanaan dan observasi, dosen model melakukan penyelenggaraan PBM dan observer melakukan observasi dengan mencatat apa saja yang diamati saat proses pembelajaran berlangsung sesuai poin-poin yang telah tersedia dalam lembar observasi. Mengawali pekuliahan dosen menyampaikan tujuan pembelajaran dan topik yang akan dibahas. Setelah itu membagi mahasiswa menjadi 5 kelompok dengan anggota kelompok terdiri dari 4 mahasiswa. Selanjutnya mahasiswa berdiskusi secara berkelompok untuk menyelesaikan tugas yang diberikan di bawah bimbingan dosen. Dalam hal ini dosen tidak serta merta membiarkan mahasiswa tetapi menjadi fasilitator. Observer mengamati dan mencatat aktivitas mahasiswa dalam lembar observasi dan melakukan perekaman. Selanjutnya, mahasiswa mempresentasikan hasil praktikumnya di depan kelas dan dosen melakukan rangkuman guna menguatkan materi.

\section{Refleksi}

Setelah perkuliahan selesai maka dilakukan refleksi atas jalannya perkuliahan. Observer dan dosen model membahas kelebihan dan kekurangan yang terjadi selama perkuliahan berlangsung. Terjadi perubahan pada kerjasama mahasiswa dengan 2 kali pertemuan yang dijelaskan dalam Tabel 2 .

Dari Tabel 2 tampak bahwa secara umum telah terjadi peningkatan kualitas pembelajaran pada mata kuliah Praktik Pengolahan Sinyal Digital. Dari hasil yang diperoleh terlihat bahwa sudah mulai ada 
perubahan sikap yang positif, diskusi sudah mulai jalan dengan baik, mahasiswa sudah mulai menyesuaikan dengan pola pembelajaran yang dilakukan. Sehingga jumlah mahasiswa yang pasif menurun dan mulai berkembang (MB) untuk tidak pasif. Interaksi antar mahasiswa dalam satu kelompok sudah meningkat. Kualitas pembelajaran sudah meningkat dan terlihat dari aktivitas mahasiswa yang lebih aktif dalam mengkuti pembelajaran. Aktivitas mahasiswa meningkat ke dalam taraf Mulai
Berkembang (MB) dan Membudaya (MM). Perilaku saat diskusi kelompok semakin kompak, mahasiswa lebih mengembangkan analisisnya dengan kesiapan sumber belajar yang lebih baik yang tergolong dalam Membudaya (MM). Kerjasama mahasiswapun sudah ada menunjukkan ke arah yang lebih baik, dimana mulai Membudaya (MM) tanggungjawab dalama pengambilan keputusan dan Mulai Berkembang (MB) aktivitas mahasiswa dalam bentuk kerjasama.

Tabel 2. Hasil Refleksi

\begin{tabular}{|l|l|c|c|c|c|c|}
\hline \multicolumn{2}{|c|}{ Aspek pengamatan } & \multicolumn{5}{|c|}{ Kelompok } \\
\cline { 3 - 7 } \multicolumn{2}{|l|}{ Kerjasama } & 1 & 2 & 3 & 4 & 5 \\
\hline 1 & Tanggungjawab dalam pengambilan keputusan & & & & & \\
\hline 2 & Tidak memisahkan diri dari orang lain & $\mathrm{M}$ & $\mathrm{M}$ & $\mathrm{M}$ & $\mathrm{M}$ & $\mathrm{MM}$ \\
& & $\mathrm{B}$ & $\mathrm{M}$ & $\mathrm{M}$ & $\mathrm{M}$ & \\
\hline 3 & Interaksi terhadap sumber belajar & $\mathrm{M}$ & $\mathrm{M}$ & $\mathrm{M}$ & $\mathrm{M}$ & $\mathrm{MM}$ \\
& & $\mathrm{M}$ & $\mathrm{M}$ & $\mathrm{M}$ & $\mathrm{M}$ & \\
\hline 4 & Interaksi antar mahasiswa (dalam satu kelompok) & $\mathrm{M}$ & $\mathrm{M}$ & $\mathrm{M}$ & $\mathrm{M}$ & $\mathrm{MM}$ \\
& & $\mathrm{M}$ & $\mathrm{M}$ & $\mathrm{M}$ & $\mathrm{M}$ & \\
\hline 5 & Aktifitas menyelesaikan masalah & $\mathrm{M}$ & $\mathrm{M}$ & $\mathrm{M}$ & $\mathrm{MM}$ \\
& & $\mathrm{M}$ & $\mathrm{M}$ & $\mathrm{M}$ & $\mathrm{M}$ & \\
\hline 6 & Mahasiswa tidak Pasif & $\mathrm{M}$ & $\mathrm{M}$ & $\mathrm{M}$ & $\mathrm{M}$ & $\mathrm{MB}$ \\
& & $\mathrm{B}$ & $\mathrm{B}$ & $\mathrm{M}$ & $\mathrm{B}$ & \\
\hline
\end{tabular}

Secara keseluruhan dari pelaksanaan lesson study yang dilakukan menunjukkan bahwa terjadi peningkatan kualitas proses pembelajaran dan peningkatan kemampuan kerjasama tim. Ini dapat dilihat dari perkuliahan tidak membosankan karena sebagian besar mahasiswa kelihatan antusias dalam belajar. Bagi dosen juga ada keuntungannya yaitu dapat melakukan kolaborasi dengan teman sejawat dalam upaya untuk memperbaiki pembelajarannya. Walaupun penelitian ini menunjukkan hasil yang baik, tetapi untuk mengubah perilaku belajar bukanlah hal mudah. Maka dari itu perlu adanya keberlanjutan pelaksanaan metode ini meskipun tidak sama persis setidaknya pola perilaku yang telah dibangun dapat dipertahankan.

\section{SIMPULAN}

Berdasarkan hasil dan pembahasan yang telah dipaparkan di atas, maka dapat disimpulkan sebagai berikut:

1. Diperoleh pola pembelajaran berbasis lesson study pada mata kuliah praktik pengolahan sinyal digital untuk meningkatkan kualitas proses belajar mahasiswa, yaitu :

a. Sebelum perkuliahan berlangsung, dosen dan kolaborator menyiapkan perencanaan untuk pembelajaran 
yaitu materi kuliah, RPP, dan lembar observasi.

b. Pelaksanaan perkuliahan diawali dengan penjelasan dosen tentang materi yang akan dipraktikkan dan permasalahan yang akan diselesaikan. Kemudian dilakukan pemecahan masalah secara kelompok dan kemudian dilanjutkan dengan presentasi kelompok di depan kelas. Pada pelaksanaan perkuliahan dilakukan observasi dan pengamatan untuk mengetahui kekurangan proses pembelajaran.

c. Setelah perkuliahan selesai dilakukan refleksi untuk mengurangi kelemahan yang terjadi dalam proses pembelajaran. Sehingga dapat meningkatkan proses pembelajaran.

2. Terjadi peningkatan kualitas proses pembelajaran. Ini dapat dilihat dari jumlah mahasiswa yang aktif semakin banyak, perkuliahan tidak membosankan karena sebagian besar mahasiswa kelihatan antusias dalam belajar.

\section{DAFTAR RUJUKAN}

Amir, M. Taufiq. (2009). Inovasi pendidikan melalui problem based learning. Bagaimana pendidik memberdayakan pemelajar di era pengetahuan. Jakarta: Kencana Prenada Media Group

Arends, Richard. I. (2008). Belajar untuk mengajar. Edisi ke tujuh alih bahasa oleh helly prayitno dan sri mulyantani prayitnodari judul learning to teach $\left(7^{\text {th }}\right.$ ed). Yogyakarta : Penerbit Pustaka Pelajar.
Barbara. B. Levin. (2001). Energizing teacher education and profesional development with problem based learning. Alexandria: ASCD.

Bill Cerbin \& Bryan Kopp. A Brief Introduction to College Lesson Study. Lesson Study Project. online: http://www.uwlax.edu/sotl/lsp/index2 . htm

Johnson \& Johnson. (1991). Cooperative Learning Strategis (online): www.clcrc.com/cl.html

Lewis, Catherine C. (2002), Lesson Study : A Handbook of Teacher-Led Instructional Change, Philadelphia, PA : research for better Schools, Inc.

Linda, T. \& Sara, S. (2002). Problems as possibilities: problem-based learning for $K-16$ education. Alexandria: ASCD.

Maggi, S. \& Claire H.M. (2004). Foundations of problem-based learning. New York: Open University Press.

Rusman. (2012). Model-model pembelajaran mengembangkan profesional guru. Jakarta : Raja Grafindo Persada.

Slamet Mulyana. (2007). Lesson Study (Makalah). Kuningan: LPMP-Jawa Barat

Tan, Oon-Seng. (2004). Enhancing thingking through problem-based learning approaches. Cengage Learning. 